\title{
Recognition of Oerskovia Species in the Clinical Laboratory: Characterization of 35 Isolates
}

\author{
FRANCES O. SOTTNEK, JUNE M. BROWN, ROBERT E. WEAVER, AND GARY F. CARROLL \\ Center for Disease Control, Atlanta, Georgia 30333
}

\begin{abstract}
Fifty-seven clinical isolates of previously unidentified gram-positive, fermentative, nonsporeforming rods were studied and compared to the type strains of Oerskovia turbata and $O$. xanthineolytica. Thirty-five of the isolates were identified as Oerskovia species: 9 were identified as $O$. turbata, and 26 were identified as $O$. xanthineolytica. The Oerskovia cultures could be differentiated from the other isolates on the basis of the development of filamentous colonies.
\end{abstract}

The genus Oerskovia, described by Prauser et al. (8), Sukapure et al. (11), and emended by Lechevalier (6), consists of yellow-pigmented organisms with branched hyphae. These hyphae break up into motile, rodlike elements that "appear bacterial" in smears. These rods are gram positive and non-acid fast. Previously described sources of the organisms are soil, aluminum hydroxide gel antacid, and dry grass cuttings (6). During the last 20 years, the Special Bacteriology Section (SBS), Bacteriology Division, Center for Disease Control (CDC), has received for identification a number of motile, gram-positive, nonsporeforming, yellow pigment-producing organisms isolated from clinical sources. These organisms were not recognized as belonging to any established species and were arbitrarily designated as group A Corynebacterium sp. Later, this group was divided into five subgroups, primarily on the basis of carbohydrate reactions. When these isolates were observed to have characteristics similar to those reported for the genus Oerskovia, a collaborative study between the Actinomycete Laboratory of CDC's Mycology Division and the SBS was initiated to further characterize and classify them. Listeria denitrificans was included in this study because two of our colleagues, D. Hollis and G. Wiggins, had noted during earlier work on the genus Listeria that many biochemical characteristics of this species were similar to those of the group A strains.

\section{MATERIALS AND METHODS}

Isolates. The isolates studied are listed in Table 1. The type strains Oerskovia turbata ATCC 25835 and $O$. xanthineolytica ATCC 27402 were supplied by M. P. Lechevalier. An isolate of $L$. denitrificans, ATCC 14870 , was sent to us by H. J. Welshimer.

Morphology. All cultures were incubated at $35^{\circ} \mathrm{C}$ unless otherwise noted. Gram stains were made from 24 -h heart infusion agar slant cultures. A mod- ified Ziehl-Neelsen method (4) was used for acid-fast stains. Flagella were stained by the Leifson technique (7). Each isolate was cultured on heart infusion agar (HIA; Difco) and Trypticase soy agar (TSA; BBL) plates. Colonial morphology was observed by a light microscope under low power $(\times 100$ magnification) after $24 \mathrm{~h}, 48 \mathrm{~h}$, and 7 days of incubation.

Biochemical tests. Tests and media were those used routinely in the SBS and the Actinomycete Laboratory, and have been previously described (1, 2,5 ).

Whole cell analyses. The methods used for diaminopimelic acid analysis and monosaccharide analysis are those described by Berd (1).

\section{RESULTS}

Gram stains from 24-h HIA slant cultures of the group A-1 and A-2 isolates examined showed variation from gram positive to gram negative. Most appeared to be gram variable. Cellular morphology varied a great deal. Some isolates were similar to the type strain of $O$. turbata (Fig. 1a) and were filamentous, with rudimentary branched and round forms (Fig. 1b). Other isolates resembled the type strain of $O$. xanthineolytica (Fig. 1c) and were predominantly coccoid, with a few medium-long rods (Fig. 1d). Most isolates showed variations between these two extremes. $L$. denitrificans stained gram positive and had short, straight, to long, curved rods (Fig. 2). Groups A-3, A-4, and A-5 stained gram variable or gram positive and, although most isolates were short to medium, rather thin rods, two isolates were decidedly diphtheroidal, and two others were filamentous, with rudimentary branching.

Flagella stains were done on all of the cultures studied. One to five polar or lateral flagella, or both, were seen on smears of all motile isolates (Fig. 3). Flagella were not detected on the three nonmotile group A-1 and A-2 isolates (C9205-6, B6934, D4746) or on the other nonmotile group A isolates. 
TABLE 1. Isolates used in this study

\begin{tabular}{|c|c|c|}
\hline Name & SBS no. & Source \\
\hline $\begin{array}{l}\text { Oerskovia turbata } \\
\quad \text { ATCC } 25835\end{array}$ & $\mathrm{KC} 1355$ & Soil \\
\hline O. turbata & $\mathrm{C} 4239$ & Unknown (human) \\
\hline O. turbata & C5519 & Heart valve \\
\hline O. turbata & C5520 & Heart valve \\
\hline O. turbata & C5614 & Heart valve \\
\hline O. turbata & C5918 & Tissue \\
\hline O. turbata & C5919 & Tissue \\
\hline O. turbata & C6926 & Heart tissue \\
\hline O. turbata & C6927 & Heart tissue \\
\hline O. turbata & $\mathrm{C} 8821$ & Blood \\
\hline $\begin{array}{l}\text { Oerskovia xanthineolytica } \\
\quad \text { ATCC } 27402\end{array}$ & KC1356 & Aluminum hydroxide gel antacid \\
\hline O. xanthineolytica & KC1332 & Sputum \\
\hline O. xanthineolytica & 2425 & Urine \\
\hline O. xanthineolytica & 2681 & Blood \\
\hline O. xanthineolytica & 5488 & Blood \\
\hline O. xanthineolytica & 9359 & Right ethmoid \\
\hline O. xanthineolytica & A3824 & Heart \\
\hline O. xanthineolytica & $\mathrm{A} 4212$ & Blood \\
\hline O. xanthineolytica & A7595 & Cerebrospinal fluid \\
\hline O. xanthineolytica & A8249 & Blood \\
\hline O. xanthineolytica & A8307 & Tear duct \\
\hline O. xanthineolytica & $\mathrm{B} 559(1)$ & Sputum \\
\hline O. xanthineolytica & B4827 & Urine \\
\hline O. xanthineolytica & $\mathrm{B} 6165$ & Urine \\
\hline O. xanthineolytica & $\mathrm{B} 6934(\mathrm{~A})$ & Leg wound \\
\hline O. xanthineolytica & $\mathrm{C} 2886$ & Left tibia \\
\hline O. xanthineolytica & C4861 & Urine \\
\hline O. xanthineolytica & C5541 & Blood \\
\hline O. xanthineolytica & C7119 & Blood \\
\hline O. xanthineolytica & C7315 & Left eye drainage \\
\hline O. xanthineolytica & C9205-6 & Liver biopsy \\
\hline O. xanthineolytica & D334 & Lung \\
\hline O. xanthineolytica & D1217 & Granuloma, hand \\
\hline O. xanthineolytica & D3494 & Leg wound \\
\hline O. xanthineolytica & D3580 & Blood \\
\hline O. xanthineolytica & D4746 & Blood \\
\hline O. xanthineolytica & D4865 & Wound, knee \\
\hline SBS Group A-3 & A3936 & Blood \\
\hline SBS Group A-3 & $\mathrm{C} 2508$ & Blood \\
\hline SBS Group A-3 & $\mathrm{C} 8262$ & Cerebrospinal fluid \\
\hline SBS Group A-3 & D2991 & Cerebrospinal fluid \\
\hline SBS Group A-3 & D3060 & Pilonidal cyst \\
\hline SBS Group A-3 & D3505 & Blood \\
\hline SBS Group A-4 & $\mathrm{C} 4603$ & Ear \\
\hline SBS Group A-4 & C5206 & Urine \\
\hline SBS Group A-4 & C6391 & Pleural fluid \\
\hline SBS Group A-4 & $\mathrm{C} 8412$ & Enfamil \\
\hline SBS Group A-4 & C8759 & Unknown \\
\hline SBS Group A-4 & $\mathrm{D} 225$ & Blood \\
\hline SBS Group A-4 & D640 & Incision drainage \\
\hline SBS Group A-4 & D3562 & Sputum \\
\hline SBS Group A-5 & 6905 & Blood \\
\hline SBS Group A-5 & 9846 & Cerebrospinal fluid \\
\hline SBS Group A-5 & A5085 & Cerebrospinal fluid \\
\hline SBS Group A-5 & B3576 & Wound \\
\hline SBS Group A-5 & B4407 & Cerebrospinal fluid \\
\hline SBS Group A-5 & $\mathrm{C} 2375$ & Blood \\
\hline SBS Group A-5 & C6166 & Back lesion \\
\hline SBS Group A-5 & $\mathrm{C} 6210$ & Blood \\
\hline $\begin{array}{l}\text { Listeria denitrificans } \\
\quad \text { ATCC } 14870\end{array}$ & KC1082 & Ox blood \\
\hline
\end{tabular}




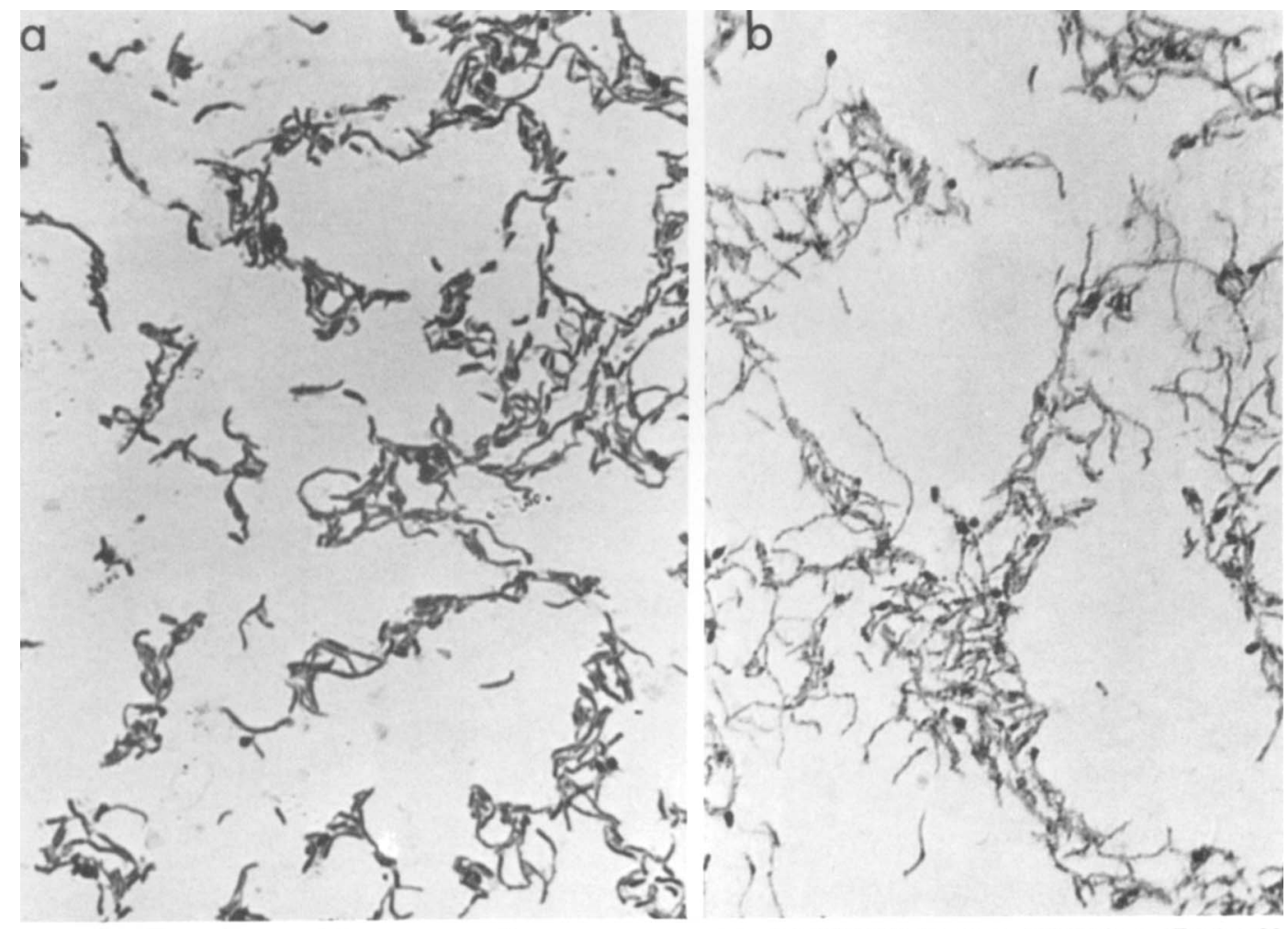

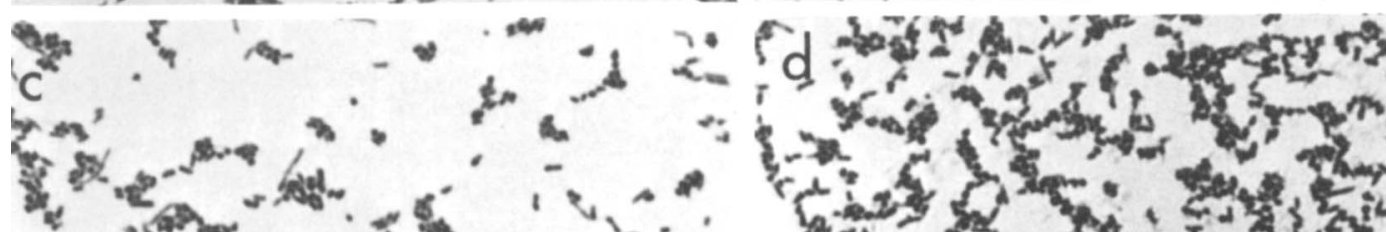

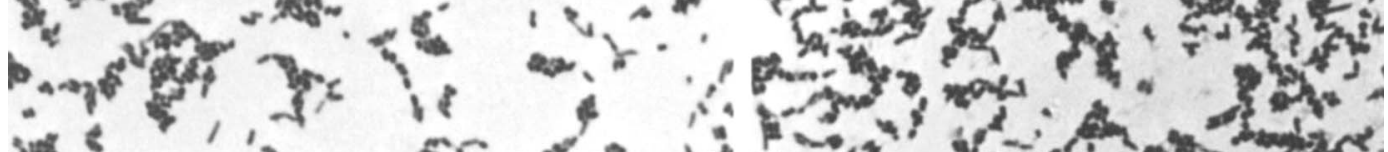

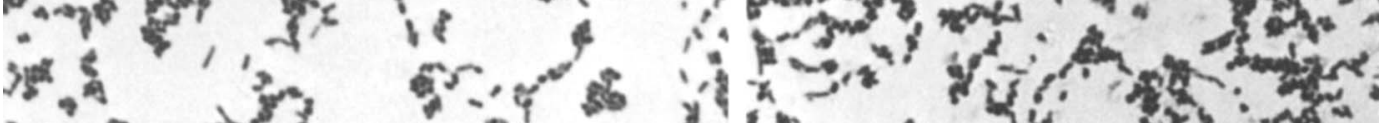
5 in

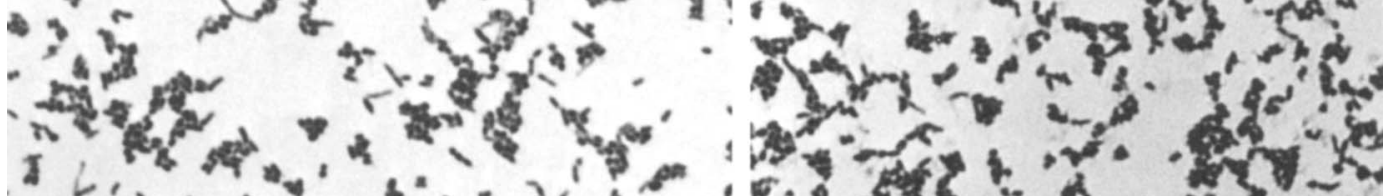

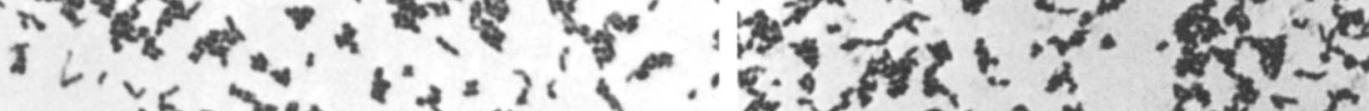

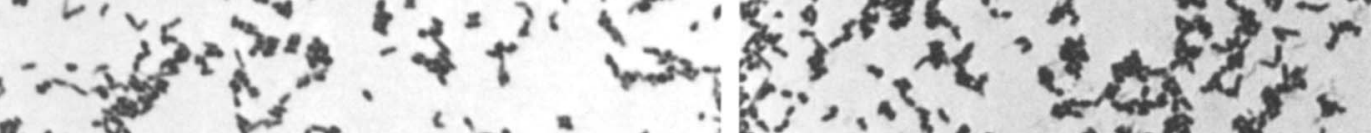
r. of

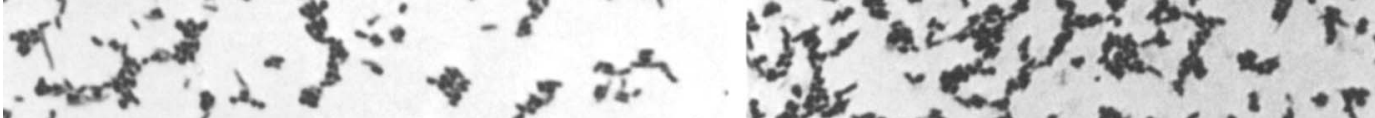

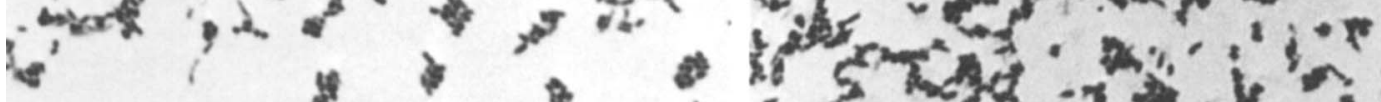

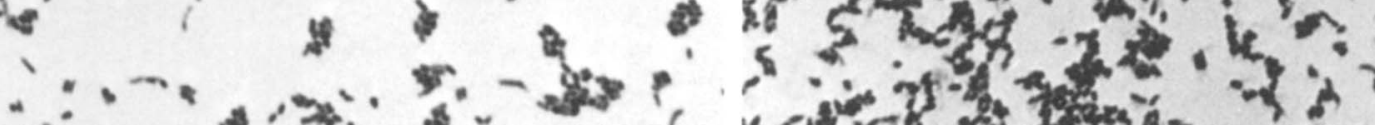

FIG. 1. Gram stain from 24-h HIA slants showing variation in cellular morphology within Oerskovia species. Magnification, $\times 1,375$. (a) Oerskovia turbata (KC1355); (b) O. xanthineolytica (A8307); (c) $O$. xanthineolytica (KC1356); (d) O. turbata (C5614). 


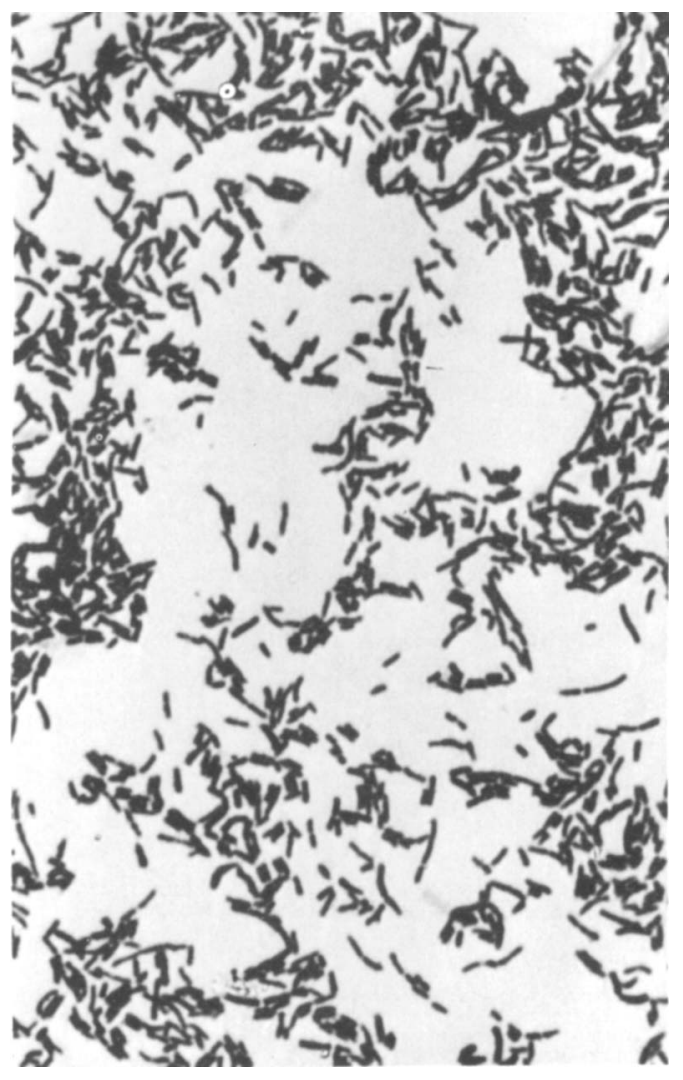

FIG. 2. Listeria denitrificans (KC1082). Gram stain from 24- $h$ HIA slant. Magnification, $\times 1,375$.

The colonial morphology of all group A-1 and A-2 isolates on 24- and 48-h HIA and TSA plates was similar to that of both of the type strains of Oerskovia sp. Colonies varied from 1 to $2 \mathrm{~mm}$ in diameter, and all had vegetative hyphae in 24 $h$. Young colonies were filamentous with distinct centers. Mature colonies developed dense centers with a filamentous fringe that was so short on some colonies that it was barely visible (Fig. 4). No aerial mycelia were seen after 7 days of incubation. All except two isolates (C6927 and D3494) produced a yellow, nonsoluble pigment. $L$. denitrificans was nonpigmented and produced smooth, convex colonies with entire edges in $24 \mathrm{~h}$. After 48 to $72 \mathrm{~h}$, filaments were formed which radiated from the center of the colony and grew into and on the surface of the agar (Fig. 5). Hyphae were not seen on any of the group A-3, A-4, or A-5 cultures during 7 days of observation.

Biochemical reactions and other characteristics are listed in Table 2. O. turbata, O. xanthineolytica, and all of the organisms in groups A-
1 and A-2 liquefied gelatin within the 14-day incubation period. Neither $L$. denitrificans nor the organisms in group A-3 liquefied gelatin, and, since their biochemical reactions were very similar to those of Oerskovia sp., the gelatin liquefaction test seems to be useful for differentiation.

Carbohydrate fermentation results listed in Table 2 were obtained in the fermentation broth base (2) routinely used in the SBS laboratory. Numerous fermentation tests were also done in the Actinomycete Laboratory with Gordon's carbohydrate base (3). With the carbohydrates tested, results were the same in both bases. Cellobiose, inulin, dextrin, glycogen, erythritol, melibiose, and melezitose, however, were not tested in Gordon's base. Temperature studies on all group A-1 and A-2 isolates were done on TSA slants, in addition to tryptoneglucose-yeast extract agar slants; the slants were incubated overnight in warm air at 25,35 , and $42^{\circ} \mathrm{C}$. Results obtained with the two media varied only slightly. Nine isolates of groups A-1 and A-2 hydrolyzed casein but did not hydrolyze xanthine, hypoxanthine, or tyrosine. They resembled $O$. turbata in this respect. The remaining 26 isolates of groups A-1 and A-2, like $O$. xanthineolytica, hydrolyzed casein, xanthine, and hypoxanthine. $L$. denitrificans did not decompose either casein, xanthine, or hypoxanthine. Although casein and hypoxanthine hydrolysis tests gave reproducible results with all of the isolates, nine cultures of groups A-1 and A-2 were inconsistent in their ability to hydrolyze xanthine. However, when plates were incubated at a constant $28^{\circ} \mathrm{C}$ rather than at room temperature, this problem was eliminated, and all nine isolates hydrolyzed xanthine in 14 days. None of the isolates in group A-3, A-4, or A-5 hydrolyzed xanthine or hypoxanthine. Casein was hydrolyzed by two of the group A-5 isolates.

Whole cell analyses of the organisms in groups A-1 and A-2 indicated that they contained neither the meso- nor the L-isomer of diaminopimelic acid. Furthermore, as Lechevalier reported (6), galactose was the only characteristic whole cell sugar found in either the Oerskovia sp. or the isolates in groups A-1 and A-2.

\section{DISCUSSION}

Fifty-seven clinical isolates received for identification by the SBS during the last 20 years and formerly designated group A Corynebacterium sp. were studied. Of these, 35 isolates are now identified as Oerskovia sp. All 35 isolates were formerly included in groups A-1 and A-2. 


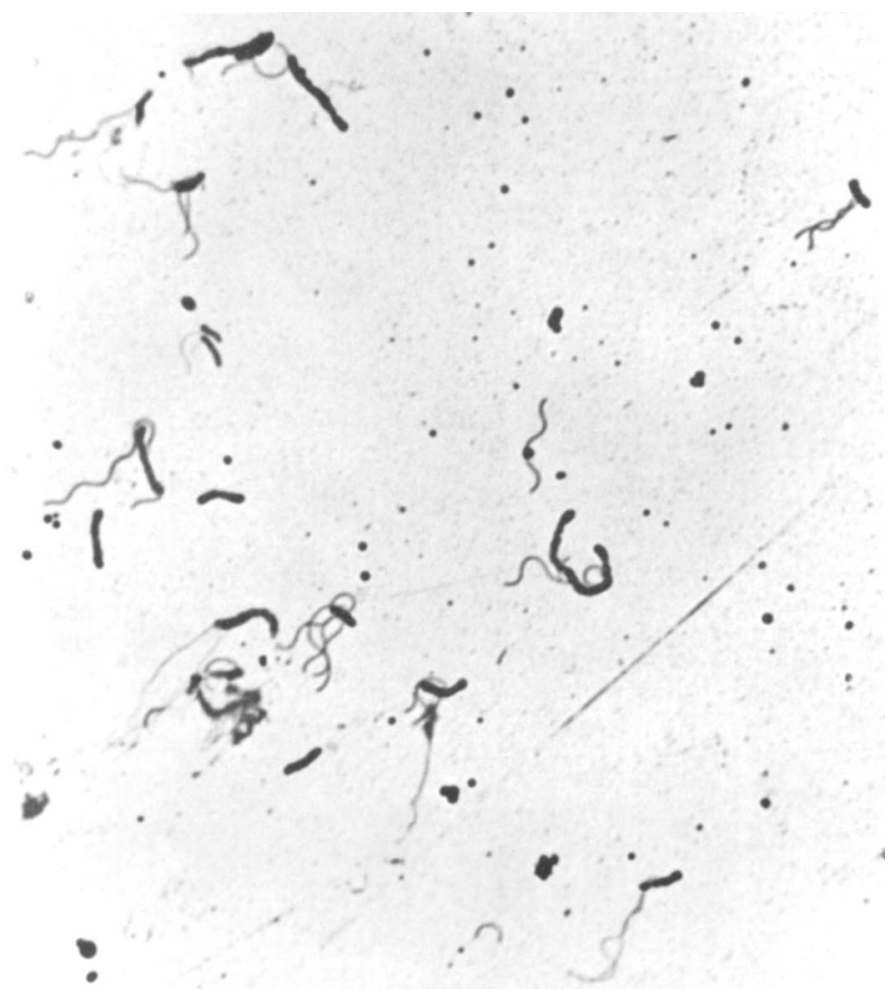

FIG. 3. O. turbata. Flagella stain from 24-h rabbit blood agar plate. Magnification, $\times 1,375$. 
TABLE 2. Characteristics of isolates of Oerskovia sp., group A Corynebacterium sp., and Listeria denitrificans ${ }^{a}$

\begin{tabular}{|c|c|c|c|c|c|c|c|c|}
\hline Characteristics $^{b}$ & $\begin{array}{c}\text { O. tur- } \\
\text { bata } \\
\text { ATCC } \\
25835\end{array}$ & $\begin{array}{c}\text { Groups } \\
\text { A-1 and } \\
-2(O . \\
\text { tur- } \\
\text { bata }) \\
9 \text { iso- } \\
\text { lates }\end{array}$ & $\begin{array}{l}\text { O. xanthi- } \\
\text { neolytica } \\
\text { ATCC } 27402\end{array}$ & $\begin{array}{c}\text { Groups A-1 } \\
\text { and }-2(O . \\
\text { xanthineoly- } \\
\text { tica), } \\
26 \text { isolates }\end{array}$ & $\begin{array}{l}\text { Group } \\
\text { A-3, } \\
6 \text { iso- } \\
\text { lates }\end{array}$ & $\begin{array}{c}\text { Group } \\
\text { A-4, } \\
8 \text { iso- } \\
\text { lates }\end{array}$ & $\begin{array}{c}\text { Group } \\
\text { A-5, } \\
8 \text { iso- } \\
\text { lates }\end{array}$ & $\begin{array}{c}\text { L. denitri- } \\
\text { ficans } \\
\text { ATCC } \\
14870\end{array}$ \\
\hline $\begin{array}{l}\text { Vegetative hyphae }^{c} \text { on } \\
\text { TSA and HIA }\end{array}$ & + & + & + & + & - & - & - & + \\
\hline Motility & + & + & + & $+(3)$ & + & $+(3)$ & $-(3)$ & + \\
\hline Yellow growth pigment & + & $+(1)$ & + & $+(1)$ & - & $+(2)$ & + & - \\
\hline OF glucose & $\mathbf{F}$ & $\mathbf{F}$ & $\mathrm{F}$ & $\mathrm{F}$ & $\mathbf{F}$ & $\mathbf{F}$ & $\mathrm{F}$ & $\mathbf{F}$ \\
\hline Gelatinase & + & + & + & + & - & $-(1)$ & $-(2)$ & - \\
\hline Nitrate reduction & + & $-(1)$ & + & $+(1)$ & + & $-(1)$ & $+(1)$ & + \\
\hline \multicolumn{9}{|l|}{ Acid from: ${ }^{d}$} \\
\hline Glucose & + & + & + & + & + & + & + & + \\
\hline Xylose & + & + & + & + & + & + & - & + \\
\hline Mannitol & - & - & - & - & - & + & + & - \\
\hline Lactose & + & $+(3)$ & + & $+(7)$ & + & + & $-(3)$ & + \\
\hline Sucrose & + & + & + & + & + & + & + & + \\
\hline Maltose & + & + & + & + & + & + & + & + \\
\hline Glycerol & + & $+(2)$ & + & $+(1)$ & $+(1)$ & $-(2)$ & $+(3)$ & + \\
\hline Arabinose & + & + & + & + & + & + & $-(3)$ & + \\
\hline Mannose & + & + & + & + & + & + & $+(1)$ & + \\
\hline Rhamnose & - & - & - & - & + & $+(3)$ & $-(2)$ & - \\
\hline Raffinose & - & - & + & $-(3)$ & $+(2)$ & $-(2)$ & $-(2)$ & + \\
\hline Sorbitol & - & - & - & - & $-(2)$ & $-(2)$ & $-(1)$ & - \\
\hline Inulin & - & - & - & $-(2)$ & - & $-(1)$ & - & - \\
\hline Dextrin & + & + & + & $+(1)$ & + & + & $+(2)$ & + \\
\hline Glycogen & + & + & + & + & - & $-(2)$ & $+(1)$ & + \\
\hline Melibiose & - & - & + & $-(6)$ & $+(1)$ & $+(4)$ & $-(3)$ & + \\
\hline Melezitose & - & - & - & $-(2)$ & $-(2)$ & - & $-(2)$ & + \\
\hline Starch & + & + & + & + & $-(2)$ & $+(3)$ & + & + \\
\hline \multicolumn{9}{|l|}{ Growth on TGY agar at: } \\
\hline $25^{\circ} \mathrm{C}$ & + & + & + & + & + & + & $+(1)$ & + \\
\hline $35^{\circ} \mathrm{C}$ & + & + & + & + & + & + & + & + \\
\hline $42^{\circ} \mathrm{C}$ & - & $+(1)$ & + & $+(2)$ & $+(2)$ & $-(1)$ & $+(2)$ & + \\
\hline Urea hydrolysis & - & $+(2)$ & + & $+(10)$ & - & - & $-(1)$ & - \\
\hline $\begin{array}{l}\text { Growth in NB with } 6 \% \\
\mathrm{NaCl}\end{array}$ & - & $+(3)$ & + & $+(5)$ & $+(3)$ & $-(2)$ & $-(3)$ & + \\
\hline \multicolumn{9}{|l|}{ Whole cell analyses: } \\
\hline $\mathrm{DAP}^{e}$ & - & - & - & - & - & $-(1)$ & $-(1)$ & - \\
\hline Galactose & + & + & + & + & $+(2)$ & + & $+(2)$ & - \\
\hline \multicolumn{9}{|l|}{ Hydrolysis of: } \\
\hline Casein & + & + & + & + & - & - & $-(2)$ & - \\
\hline Xanthine & - & - & + & + & - & - & - & - \\
\hline Hypoxanthine & - & - & + & + & - & - & - & - \\
\hline Tyrosine & - & - & - & $-(1)$ & - & - & - & - \\
\hline
\end{tabular}

${ }^{a}$ Numbers in parentheses indicate the number of isolates that varied from the recorded result. All isolates hydrolyzed esculin and were catalase positive. No isolates utilized citrate, produced indole, or stained acid fast positive. Tests for oxidase, MR-VP, and reactions in litmus milk were variable within all groups.

${ }^{b}$ Abbreviations: TSA, Trypticase soy agar; HIA, heart infusion agar; TGY, tryptone-glucose-yeast extract; NB, nutrient broth; F, fermentative; O, oxidative; DAP, diaminopimelic acid.

c No aerial mycelium produced on plate or slide cultures.

${ }^{d}$ Results recorded were obtained in fermentation broth base. All isolates produced acid from galactose, levulose, trehalose, cellobiose, and salicin. No strains produced acid from adonitol, dulcitol, inositol, or erythritol.

e DAP, when present, was in the meso form. 
All of the organisms that had been included in groups A-3, A-4, and A-5 apparently do not belong in the genus Oerskovia, and their identity remains uncertain at the present time.

We speciated the 35 Oerskovia isolates. Nine proved to be $O$. turbata, and 26 were identified as $O$. xanthineolytica solely on the basis of the ability of the latter to hydrolyze xanthine and hypoxanthine. In contrast to Lechevalier's findings, we found that growth on TSA at $42^{\circ} \mathrm{C}$ was a variable characteristic for both species. Lechevalier (personal communication, 1976) clarified the differences that we noted in the production of acid from raffinase. After examining some of our strains of $O$. xanthineolytica, she now believes that this character should be considered variable for $O$. xanthineolytica.

The nine isolates, now identified as $O$. turbata, were received by the SBS during a 15month period (1972 to 1974), and all but one (C4239) were sent from the same geographical area (Colorado) (9). Unfortunately, we have been unable to obtain any information about

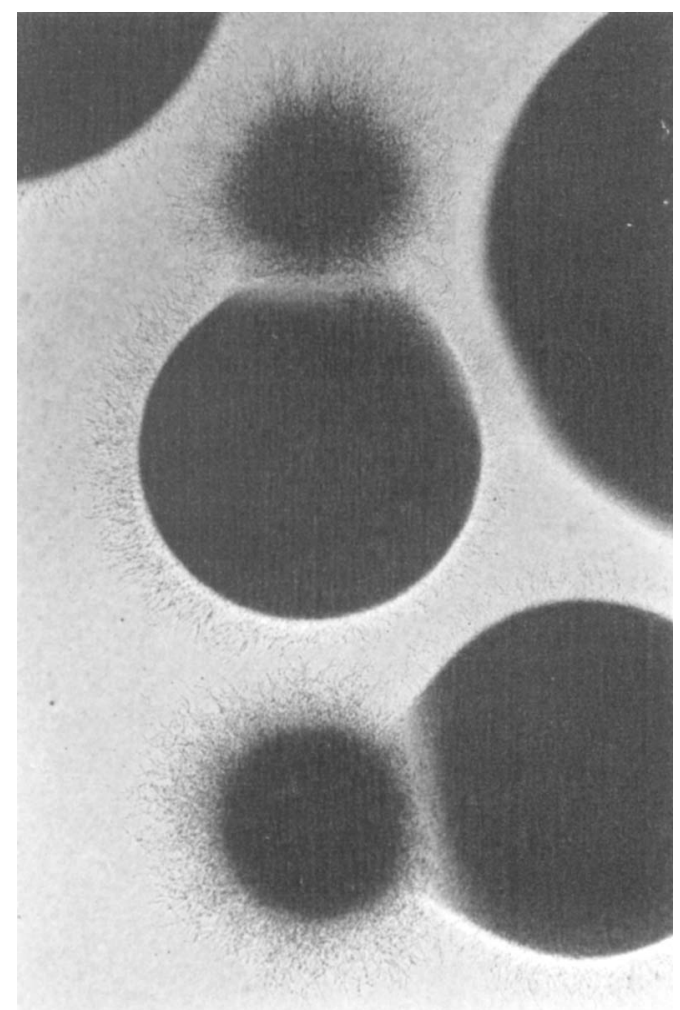

FIG. 4. O. xanthineolytica (KC1356). Colonies producing vegetative hyphae on 48-h TSA plate. Magnification, $\times 100$.

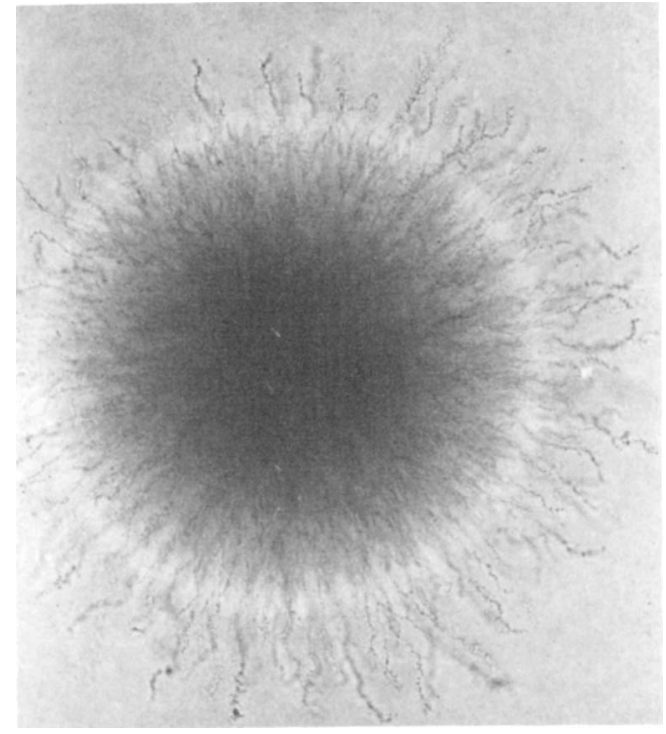

FIG. 5. L. denitrificans (KC1082). Colonies producing vegetative hyphae on 72-h TSA plate. Magnification, $\times 100$.

the source of isolate C4239, other than that it was from a human.

As noted in Table 1, the sources of the $O$. xanthineolytica isolates varied widely. The fact that eight cultures were isolated from human blood would seem to indicate clinical significance, but, unfortunately, we have been unable to obtain satisfactory case histories on these patients.

The biochemical characteristics of $L$. denitrificans closely resemble those of the Oerskovia species. The only differences that we found were gelatinase production, fermentation of melezitose, and casein hydrolysis. On the basis of whole cell analyses, however, we do not believe that $L$. denitrificans should be included in this genus. $L$. dentrificans produced branched vegetative hyphae on HIA and TSA plates. Stuart and Welshimer have suggested that serious consideration be given to reclassifying $L$. denitrificans (10). Our findings support their suggestion.

\section{ACKNOWLEDGMENTS}

We thank Mary P. Lechevalier for her advice and encouragement, Don Howard for photomicrographs, and Libero Ajello for his suggestions in the preparation of this manuscript.

\section{REPRINT REQUESTS}

Address reprint requests to: Frances O. Sottnek, Center for Disease Control, Atlanta, GA 30333. 


\section{LITERATURE CITED}

1. Berd, D. 1973. Laboratory identification of clinically important aerobic Actinomycetes. Appl. Microbiol. 25:665-681.

2. Ewing, W. H., and B. R. Davis. 1970. Media and tests for differentiation of Enterobacteriaceae. Center for Disease Control, Atlanta, Ga.

3. Gordon, R. E., W. C. Haynes, and C. Hor-Nay Pang. 1973. The genus Bacillus. Agriculture Handbook no. 427, U.S. Department of Agriculture. Government Printing Office, Washington, D.C.

4. Gray, P. 1954. The microtomist's formulary and guide. Blakiston Co., Inc., New York.

5. King, E. O. 1967. The identification of unusual pathogenic gram negative bacteria. Center for Disease Control, Atlanta, Ga.

6. Lechevalier, M. P. 1972. Description of a new species,
Oerskovia xanthineolytica, and emendation of Oerskovia Prauser et al. Int. J. Syst. Bacteriol. 22:260-264.

7. Leifson, E. 1951. Staining, shape, and arrangement of bacterial flagella. J. Bacteriol. 62:377-389.

8. Prauser, H., M. P. Lechevalier, and H. Lechevalier. 1970. Description of Oerskovia gen. n. to harbor Orskov's motile Nocardia. Appl. Microbiol. 19:534.

9. Reller, L. B., G. L. Maddoux, M. R. Eckman, and G. Pappas. 1975. Bacterial endocarditis caused by Oerskovia turbata. Ann. Intern. Med. 83:664-666.

10. Stuart, S. E., and H. J. Welshimer. 1973. Intragenic relatedness of Listeria Pirie. Int. J. Syst. Bacteriol. 23:8-14.

11. Sukapure, R. S., M. P. Lechevalier, H. Reber, M. L. Higgins, H. A. Lechevalier, and H. Prauser. 1970. Motile nocardoid Actinomycetales. Appl. Microbiol. 19:527-533: 